Al Maal : Journal of Islamic Economics and Banking

http://jurnal.umt.ac.id/index.php/jieb

E-ISSN : $2580-3816$

Vol : $\quad 3$ No. 1 Bulan Juli Tahun 2021

Hlm : $\quad 35-48$

DOI : $\quad 10.31000 /$ almaal.v3i1.4641

\title{
Pengaruh Inflasi, BI 7-Day Reserve Repo Rate, Dana Pihak Ketiga, Dan Fee Based Income Terhadap Profitabilitas BNI Syariah Tahun 2015-2020
}

\author{
Badi' Rizqi Aminulloh", ${ }^{1}$, Dedi Suselo \\ 1,2, Prodi Perbankan Syariah, Fakultas Ekonomi dan Bisnis Islam, UIN Sayyid Ali Rahmatullah \\ Tulungagung, Indonesia \\ *aminullohrizqi898@gmail.com
}

\section{ABSTRACT}

This study was find out and conducted the effect of variables macro economics and source of income funds on profitability of BNI Syariah, with inflation, BI 7-day reserve repo rate, third party funds and fee based income as a research variable. The population in this study is a monthly financial statements of BNI Syariah in 2015-2020. The sample was determined by a purposive sampling method - 68 samples. The method used in this research is descriptive method with quantitative approach. The data used in this research is in the form of monthly financial statements that have been published by BNI Syariah (Persero) Tbk as well as data published by Bank Indonesia. The data test techniques in this study used normality test, multicolinearity test, heterocysticity test, autocorrelation test, multiple linear analysis and determination coefficient. The results of this study stated that partially inflation and BI 7-day reserve repo rate have no significant effect on profitability of BNI Syariah (Persero) Tbk. While the variables of third party funds and fee based income partially have a positive significant effect on profitability of BNI Syariah (Persero) Tbk for the period 2015 until 2020.

Keywords: Macro Economic; Third Party Funds; Fee Based Income; Profitability.

\section{ABSTRAK}

Penelitian ini bertujuan untuk mengetahui dan membuktikan pengaruh variabel makro ekonomi dan sumber pendapatan dana pada bank terhadap profitabilitas BNI Syariah, inflasi dan BI 7day reserve repo rate, dana pihak ketiga dan fee based income sebagai variabel penelitian. Populasi dalam penelitian ini adalah laporan keuangan bulanan BNI Syariah tahun 2015-2020. Sampel ditentukan dengan metode purposive sampling sehingga diperoleh 68 sampel. Metode yang digunakan dalam penelitian ini adalah metode deskriptif dengan pendekatan kuantitatif. Data yang digunakan dalam penelitian ini berupa laporan keuangan bulanan yang telah dipublikasikan oleh BNI Syariah (Persero) Tbk serta data yang dipublikasikan oleh Bank Indonesia. Teknik uji data dalam penelitian ini menggunakan uji normalitas, uji multikolinearitas, uji heterokedastisitas, uji autokorelasi, analisis linear berganda dan koefisien determinasi. Hasil dari penelitian ini menyatakan bahwa secara parsial inflasi dan BI 7-day reserve repo rate tidak berpengaruh secara signifikan terhadap profitabilitas BNI Syariah (Persero) Tbk. Sedangkan variabel dana pihak ketiga dan fee based income berpengaruh positif signifikan terhadap profitabilitas BNI Syariah (Persero) Tbk periode 2015-2020.

Kata kunci : Makroekonomi; Dana Pihak Ketiga; Fee Based Income; Profitabilitas. 


\section{Pendahuluan}

Industri perbankan merupakan salah satu pendukung dan penyokong perekonomian yang utama pada suatu negara, perkembangan industri perbankan khususnya perbankan syariah dinilai cukup baik selama kurun waktu 5 tahun terakhir. Keberhasilan bank syariah dalam menyokong perekonomian dapat diliat dari aspek nilai profitabilitas yang berhasil dibukukan. Alasan bank syariah mendulang profitabilitas yang cederung stabil dan produktif didukung dengan sistem operasionalnya yang tidak menggunakan sistem bunga, hal tersebut membuat bank syariah lebih struggle dalam menghadapi gunjangan ekonomi yang sedang terjadi. Dalam beberapa penelitian menyatakan bahwa profitabilitas bank dipengaruhi oleh variabel makroekonomi berupa inflasi, BI rate ( BI 7-day reserve repo rate), serta faktor penghimpunan dana atau dana pihak ketiga dan fee based income.

Inflasi didefinisikan sebagai suatu kondisi dimana kenaikan jumlah uang yang beredar atau kenaikan likuiditas dalam suatu perekonomian seperti yang dikemukakan oleh (Suseno dan Siti Astiyah, 2009:2). Tinggi rendahnya inflasi berdampak pada sektor perbankan syariah dalam mendapatkan profitabilitas. Menurut (Pratama Rahardja dan Mandala Manurung, 2008:359) Tinggi rendahnya tingkat inflasi dapat berdampak buruk terhadap individu dan masyarakat karena menurunnya tingkat kesejahteraan masyarakat dan buruknya distribusi pendapatan. Dalam penelitian yang telah dilakukan oleh $\mathrm{G}$. Kalengkongan (2013) dengan judul: Tingkat Suku Bunga dan Inflasi Pengaruhnya Terhadap Return On Asset (ROA) Pada Industri Perbankan Yang Go Public Di Bursa Efek Indonesia, memperoleh hasil secara parsial dan simultan bahwa tingkat suku bunga dan inflasi berpengaruh terhadap profitabilitas.

Penelitian lain yang dilakukan oleh N. W. Lindayani \& S. Kt. S. Dewi dengan judul: Dampak Struktur Modal dan Inflasi Terhadap Profitabilitas dan Return Saham Perusahaan Keuangan Sektor Perbankan, memperoleh hasil bahwa inflasi berpengaruh signifikan terhadap profitabilitas. Adapun penelitian yang dilakukan oleh Edhi Satria Wibowo dan Muhammad Syaichu (2013) yang berjudul: Analisis Pengaruh Suku Bunga, Inflasi, CAR, BOPO, NPF Terhadap Profitabilitas Bank Syariah, memperoleh hasil bahwa inflasi berpengaruh tidak signifikan terhadap profitabilitas.

Variabel makroekonomi lain yang juga mempengaruhi profitabilitas perbankan yaitu suku bunga acuan atau BI Rate dan berganti nama menjadi BI 7-day reserve repo rate yang berlaku mulai 19 Agustus 2016. Suku bunga acuan merupakan suku bunga kebijakan yang menggambarkan stance kebijakan moneter yang ditetapkan oleh Bank Indonesia dan diumumkan kepada publik. Penetapan suku bunga acuan atau BI 7-day reserve repo rate mempunyai dampak yang secara langsung dirasakan oleh sektor perbankan. Tingkat bunga merupakan harga dari kredit yang harus dibayar oleh peminjam untuk mendapatkan dana dari pemberi pinjaman dalam jangka waktu yang telah disepakati. Teori yang dikemukakan oleh (J. M. Keynes, 2018:146) menyatakan bahwa tingkat suku bunga memberikan kecenderungan fungsional yang menentukan jumlah uang yang diberikan, hal ini berpengaruh terhadap perilaku masyarakat yang ingin menghindari risiko dan memaksimalkan keuntungan.

Penelitian yang telah dilakukan oleh A. Y. Sahara (2013) yang berjudul: Analisis Pengaruh Inflasi, Suku Bunga BI, Dan Produk Domestik Bruto Terhadap Return On Assets (ROA) Bank Syariah Di Indonesia, memperoleh hasil secara parsial suku bunga berpengaruh negatif terhadap ROA pada bank syariah di Indonesia tahun 2008-2010. 
Penelitian lain yang dilakukan oleh T. Aldian Syah (2018) yang berjudul: Pengaruh Inflasi, BI Rate, NPF, dan BOPO Terhadap Profitabilitas Bank Umum Syariah di Indonesia, mendapatkan hasil bahwa suku bunga acuan berpengaruh signifikan terhadap profitabilitas.

Sedangkan penelitian yang dilakukan oleh Fitri Zulifiah dan Joni Susilowibowo (2014) yang berjudul: Pengaruh Inflasi, BI Rate, Capital Adequacy Ratio (CAR), Non Perfoming Loan (NPF), Biaya Operasional dan Pendapatan Operasional (BOPO) Terhadap Profitabilitas Bank Umum Syariah Periode 2008-2012, memperoleh hasil bahwa suku bunga acuan berpengaruh tidak signifikan terhadap profitabilitas.

Penghimpunan dana pihak ketiga merupakan salah satu faktor yang mempengaruhi profitabilitas bank syariah. Pada konsepnya dana pihak ketiga atau third party funds merupakan dana yang berasal dari masyarakat yang dihimpun dalam bentuk giro dan tabungan (sebagai dana murah) dan deposito (sebagai dana mahal). Menurut (Frianto Pandia, 2012:9) Dana ini mampu meraih $80 \%$ sampai 90\% dari totalitas dana yang dikelola oleh bank itu sendiri sebagai dana untuk perkreditan.

Penelitian yang dilakukan oleh S. Parenrengi \& T. W. Hendratni (2018) yang berjudul: Pengaruh Dana Pihak Ketiga, Kecukupan Modal Dan Penyaluran Kredit Terhadap Profitabilitas Bank, memperoleh hasil bahwa dana pihak ketiga berpengaruh positif dan signifikan terhadap ROA. Penelitian lain yang dilakukan oleh Dila Angraini (2018) yang berjudul: Pengaruh Dana Pihak Ketiga, Non Perfoming Financing, Tingkat Bagi Hasil Dan Modal Sendiri Terhadap Profitabilitas Dengan Pembiayaan Bagi Hasil Sebagai Variabel Intervening Pada Perbankan Syariah, memperoleh hasil bahwa variabel dana pihak ketiga berpengaruh signifikan terhadap profitabilitas.

Sedangkan penelitian yang dilakukan oleh Uus Ahmad Husaeni (2017) yang berjudul: Analisis Pengaruh Dana Pihak Ketiga Dan Non Perfoming Financing Terhadap Return On Asset Pada BPRS Di Indonesia, mendapatkan hasil bahwa pihak ketiga berpengaruh tidak signifikan terhadap profitabilitas.

Faktor yang juga mempengaruhi profitabilitas bank syariah adalah fee based income. Dalam mendapatkan keuntungan perbankan syariah tidak hanya mengacu pada sektor pembiayaan dan penyaluran kredit melainkan juga pada pendapatan provisi ataupun komisi. Penelitian yang dilakukan oleh Vivi Indah Bintari., Allicia Deana Santosa \& Risna Amalia Hamzah (2019) yang berjudul: Pengaruh Interest Based Income Dan Fee Based Income Terhadap Return On Assets Pada Bank Mandiri (PERSERO) TBK., memperoleh hasil bahwa fee based income secara parsial berpengaruh signifikan terhadap ROA pada Bank Mandiri (Persero) Tbk. Penelitian lain yang dilakukan oleh Putu Ayuni Kartika Putri Suardana dan Ketut Tanti Kustina (2017) yang berjudul: Pengaruh Fee Based Income Dan Transaksi E-Banking Terhadap Perubahan Laba Pada PT. Bank Pembangunan Daerah Bali, memperoleh hasil bahwa fee based income berpengaruh signifikan terhadap profitabilitas. Penelitian yang dilakukan oleh Gracious Madamba Massie (2014) dengan judul: Pengaruh Fee Based Income Dan Intellectual Capital Terhadap Profitabilitas Pada dustri Perbankan Di Bursa Efek Indonesia, mendapatkan hasil, bahwa fee based income berpengaruh positif tidak signifikan terhadap profitabilitas.

Berdasarkan pemaparan fenomena dan analisis gap (secara metode, periode maupun objek penelitian) atas penelitian yang pernah dilakukan, peneliti mencoba menguji kembali apakah pengaruh makroekonomi berupa inflasi dan suku bunga acuan 
(BI 7-day reserve repo rate), dana pihak ketiga dan fee based income terhadap profitabilitas perbankan syariah di Indonesia. Objek penelitian yang dipilih yaitu BNI Syariah, dengan keterbaruan data laporan keuangan dalam kurun waktu 6 tahun terakhir atau terhitung mulai 2015-2020, diharapkan dengan periode kurun waktu terbaru untuk menyempurnakan implikasi terhadap temuan penelitian.

Adapun rumusan masalah dalam penelitian ini adalah sebagai berikut : (1) Adakah pengaruh yang signifikan variabel inflasi terhadap profitabilitas BNI Syariah 2015-2020, (2) Adakah pengaruh yang signifikan variabel BI 7-Day Reserve Repo Rate terhadap profitabilitas BNI Syariah 2015-2020, (3) Adakah pengaruh yang signifikan variabel Dana Pihak Ketiga terhadap profitabilitas BNI Syariah 2015-2020, (4) Adakah pengaruh yang signifikan variabel Fee Based Income terhadap profitabilitas BNI Syariah 20152020, (5) Adakah pengaruh yang signifikan variabel inflasi, BI 7-Day Reserve Repo Rate, Dana Pihak Ketiga, dan Fee Based Income secara simultan terhadap profitabilitas BNI Syariah 2015-2020.

\section{KAJIAN LITERATUR Bank Syariah}

Bank Syariah adalah bank yang dalam menjalankan sistem operasionalnya atau kegiatan usahanya berlandaskan pada prinsip Islam, dalam operasionalnya yang menggunakan sistem pembagian risiko dan tidak menjalankan hutang berbasis bunga (Zamir Iqbal \& Abbas Mirakhor, 2013:33). Literatur lain menjelaskan bahwa keuangan Islam yang digunakan oleh bank syariah memiliki dasar yang kuat dalam agama dan mencakup sejumlah prinsip termasuk larangan riba dan gharar (Natalie Schoon, 2016:38).

\section{Inflasi}

Inflasi diartikan sebagai kenaikan jumlah uang yang beredar atau kenaikan likuiditas dalam suatu perekonomian. Menurut (Manzur Razid \& Peter Antonioni, 2015:37) inflasi digambarkan sebagai suatu kondisi dimana harga rata-rata dalam suatu perekonomian mengalami kenaikan. Menurut Pratama Rahardja dan Mandala Manurung (2008) inflasi memiliki beberapa dampak buruk terhadap individu dan masyarakat yaitu menurunnya tingkat kesejahteraan masyarakat dan buruknya distribusi pendapatan. Menurut (Farrokh K. Langdana, 2016:15) bahwa inflasi merupakan tingkat persentase dari perubahan indeks harga, dengan menggunakan produk domestik bruto deflator dan indeks harga konsumen sebagai komponen untuk mengukur inflasi.

\section{BI 7-Day Reserve Repo Rate}

BI 7-day reserve repo rate adalah suku bunga acuan dalam kebijakan baru yang menggantikan BI Rate untuk memperkuat efektivitas kebijakan dalam mencapai sasaran inflasi yang ditetapkan. Suku bunga acuan dapat dinaikan dan diturunkan nilai oleh Bank Indonesia sesuai dengan prediksi terhadap kondisi inflasi (Pusat Data dan Analisa Tempo, 2019:30). Suku bunga ini adalah instrumen yang digunakan untuk menekan atau mengendalikan laju inflasi. Teori Keynes menyatakan bahwa tingkat suku bunga memberikan kecenderungan fungsional yang menentukan jumlah uang yang diberikan, hal ini berpengaruh terhadap perilaku masyarakat yang ingin menghindari risiko dan memaksimalkan keuntungan. Literatur menyebutkan bahwa bank sentral semua negara melakukan kebijakan moneter dengan mengontrol tingkat suku bunga domestik. 


\section{Dana Pihak Ketiga}

Dana pihak ketiga adalah dana yang berasal dari masyarakat yang dihimpun dalam bentuk giro, tabungan, deposito. Dana ini bisa mencapai $80 \%$ sampai $90 \%$ dari totalitas dana yang dikelola oleh bank itu sendiri sebagai dana untuk perkreditan. Menurut (Kasmir, 2012) Dana Pihak Ketiga merupakan tolak ukur keberhasilan suatu bank apabila bank dapat menanggung biaya operasionalnya yang berasal dari dana tersebut. Literatur lain menyatakan bahwa dana pihak ketiga merupakan dana titipan yang berasal dari masyarakat dengan tujuan menitipkan dananya untuk menjamin keamanan dan keleluasaan penarikan dana sewaktu-waktu (Andrianto dan M. A. Firmansyah, 2019:164).

\section{Fee Based Income}

Fee based income menurut (S. Langgeng Ratnasari, 2012:70) adalah pendapatan yang diperoleh dari transaksi yang diberikan perbankan dalam jasa-jasa bank lainnya. Perolehan keuntungan dari jasa-jasa bank ini walaupun relatif kecil, namun memberikan suatu kepastian dikarenakan risiko terhadap jasa bank ini lebih kecil dibandingkan dengan kredit. Literatur lain (Kasmir, 2012:129) menjelaskan bahwa keuntungan yang didapat dari transaksi yang diberikan dalam jasa-jasa bank lainnya merupakan fee based income.

\section{Profitabilitas}

Profitabilitas adalah suatu rasio untuk mengukur dan menilai kemampuan yang dimiliki oleh suatu perusahaan dalam mencari keuntungan atau laba. Untuk mengukur kemampuan perusahaan dalam menghasilkan keuntungan atau profit dengan menggunakan rasio profitabilitas. Menurut (Michael Rist dan A. J. Pizzica, 2015:7) Rasio profitabilitas umumnya meliputi current yield, profit margin, return on net assets, return on equity and return on investment..

\section{Metode Penelitian}

Metode yang digunakan dalam penelitian ini adalah metode deskriptif dengan pendekatan kuantitatif, tujuan peneliti menggunakan metode ini guna menganalisis pengaruh Inflasi $\left(\mathrm{X}_{1}\right)$, BI 7-Day Reserve Repo Rate $\left(\mathrm{X}_{2}\right)$, Dana Pihak Ketiga $\left(\mathrm{X}_{3}\right)$, Fee Based Income $\left(\mathrm{X}_{4}\right)$ terhadap profitabilitas (Y) BNI Syariah tahun 2015-2020. Data yang digunakan dalam penelitian ini adalah data sekunder berupa annual report BNI Syariah tahun 2015-2020terkait data tentang dana pihak ketiga dan fee based income sedangkan data terkait dengan inflasi dan BI 7-day reserve repo rate diperoleh dari website Bank Indonesia

Teknik pengumpulan data yang digunakan dalam penelitian ini adalah dokumentasi. Teknik analisis data yang digunakan antara lain uji normalitas, uji asumsi klasik, analisis regresi linier berganda, uji hipotesis simultan (F), uji hipotesis parsial (t), dan koefisiensi determinasi $\left(\mathrm{R}^{2}\right)$. Penelitian ini menggunakan analisis regresi linier berganda dalam menguji tingkat signifikansi terkait hubungan variabel Inflasi, BI 7-day reserve repo rate, dana pihak ketiga, fee base income terhadap profitabilitas dengan menggunakan rumus :

$\mathrm{Y}=\mathrm{a}+\beta_{1} \mathrm{X}_{1}+\beta_{2} \mathrm{X}_{2}+\beta_{3} \mathrm{X}_{3}+\beta_{4} \mathrm{X}_{4}+\mathrm{e}$

Keterangan:

Y $\quad=$ Variabel dependen 


$$
\begin{array}{ll}
\mathrm{A} & =\text { Konstanta } \\
\beta & =\text { Koefisien regresi } \\
\mathrm{X} & =\text { Variabel independen } \\
\mathrm{e} & =\text { Error }
\end{array}
$$

\begin{tabular}{|c|c|c|}
\hline & & $\begin{array}{c}\text { Unstandardized } \\
\text { Residual }\end{array}$ \\
\hline$N$ & & 68 \\
\hline \multirow[t]{2}{*}{ Normal Parametersa } & Mean & .0000000 \\
\hline & $\begin{array}{l}\text { Std. } \\
\text { Deviation }\end{array}$ & .10634215 \\
\hline \multirow{3}{*}{$\begin{array}{l}\text { Most } \\
\text { Differences }\end{array}$} & Absolute & .117 \\
\hline & Positive & .117 \\
\hline & Negative & -.070 \\
\hline Kolmogorov-Smirnov Z & & .965 \\
\hline Asymp. Sig. (2-tailed) & & .309 \\
\hline
\end{tabular}

\section{Hasil dan Pembahasan}

\section{Uji Normalitas}

Tabel 1. Hasil Uji One-Sample Kolmogorov-Smirnov

Berdasarkan tabel di atas uji normalitas dengan One-Sample Kolmogorov-Smirnov Test diperoleh angka probabilitas atau Asymp. Sig. (2-tailed) sebesar 0,309. Nilai tersebut lebih besar dibandingkan dengan taraf signifikansi $(\alpha=5 \%)$ yaitu $(0,309>0,05)$. Karena nilai Asymp. Sig. (2tailed) lebih dari 0,05 maka dapat disimpulkan bahwa data

\begin{tabular}{|c|c|c|c|c|c|c|c|}
\hline \multirow[b]{2}{*}{ Model } & \multicolumn{2}{|c|}{$\begin{array}{l}\text { Unstandardized } \\
\text { Coefficients }\end{array}$} & \multicolumn{3}{|l|}{$\begin{array}{l}\text { Standardized } \\
\text { Coefficients }\end{array}$} & \multicolumn{2}{|c|}{$\begin{array}{l}\text { Collinearity } \\
\text { Statistics }\end{array}$} \\
\hline & $B$ & $\begin{array}{l}\text { Std. } \\
\text { Error }\end{array}$ & Beta & $t$ & Sig & $\begin{array}{l}\text { Toleran } \\
\text { ce }\end{array}$ & $V I F$ \\
\hline $\begin{array}{l}1 \\
\text { (Constant) }\end{array}$ & -9.183 & 1.369 & & -6.709 & $\begin{array}{l}.00 \\
0\end{array}$ & & \\
\hline Ln_Inflasi & $\begin{array}{l}-.073 \\
.020\end{array}$ & .068 & -.034 & -1.071 & $\begin{array}{l}.28 \\
8 \\
.83 \\
4\end{array}$ & .297 & $\begin{array}{l}3.36 \\
5\end{array}$ \\
\hline $\begin{array}{l}\text { Ln_BI } \\
\text { day }\end{array}$ & $\begin{array}{l}.664 \\
.917\end{array}$ & .094 & .005 & .211 & $\begin{array}{l}.00 \\
0 \\
.00 \\
0\end{array}$ & .515 & $\begin{array}{l}1.94 \\
0\end{array}$ \\
\hline $\begin{array}{l}\text { Ln_DPK } \\
\text { Ln_Fee }\end{array}$ & & .075 & .259 & $\begin{array}{l}8.853 \\
50.827\end{array}$ & & .348 & $\begin{array}{l}2.87 \\
3\end{array}$ \\
\hline based & & .018 & .895 & & & .961 & $\begin{array}{l}1.04 \\
1\end{array}$ \\
\hline
\end{tabular}
berdistribusi normal dan model regresi telah memenuhi asumsi normalitas.

Uji Multikolinearitas

Tabel 2. Output SPSS Coefficients 
Berdasarkan tabel di atas dapat diketahui bahwa nilai VIF (variance inflation factor) adalah 3,365 untuk variabel inflasi 1,940 untuk variabel BI 7-day reserve repo rate, 2,873 untuk variabel Dana Pihak Ketiga dan 1,041 untuk variabel fee based income. Hasil ini menunjukkan bahwa keempat variabel tersebut terbebas dari gangguan multikolinearitas, karena nilai VIF untuk semua variabel kurang dari 10.

\section{Uji Heteroskedastisitas (Menggunakan Uji Glejser)}

\begin{tabular}{|c|c|c|c|c|c|}
\hline & el 3. Hc & $l$ l Uji Gl & & & \\
\hline \multirow[t]{2}{*}{ Model } & \multicolumn{2}{|c|}{$\begin{array}{l}\text { Unstandardized } \\
\text { Coefficients }\end{array}$} & \multirow{2}{*}{$\begin{array}{l}\text { Standardized } \\
\text { Coefficients } \\
\text { Beta }\end{array}$} & \multirow[t]{2}{*}{$t$} & \multirow[t]{2}{*}{ Sig. } \\
\hline & $B$ & $\begin{array}{l}\text { Std. } \\
\text { Error }\end{array}$ & & & \\
\hline \multirow{5}{*}{$\begin{array}{l}\text { I(Constant) } \\
\text { Ln_inflasi } \\
\text { Ln_BI 7-day } \\
\text { Ln_DPK } \\
\text { Ln_Fee based }\end{array}$} & .443 & .762 & & .582 & .563 \\
\hline & -.060 & .038 & -.352 & - & .121 \\
\hline & .052 & .052 & .168 & .988 & .327 \\
\hline & -.014 & .042 & -.071 & -.342 & .734 \\
\hline & -.012 & .010 & -.144 & - & .251 \\
\hline
\end{tabular}

a. Dependent Variable: Abs_RES

Berdasarkan tabel di atas dapat diketahui bahwa nilai Sig. variabel inflasi sebesar 0,121, variabel BI 7-day reserve repo rate sebesar 0,327, variabel DPK sebesar 0,734 dan variabel fee based income sebesar 0,251. Karena nilai signifikansi dari seluruh variabel independen lebih dari 0,05 maka sesuai dengan dasar pengambilan keputusan dalam uji glejser dapat disimpulkan bahwa model regresi ini terbebas dari gejala heteroskedastisitas.

\section{Uji Autokorelasi}

Tabel 4. Hasil Uji Autokorelasi

\begin{tabular}{llllll}
\hline Model & $\boldsymbol{R}$ & $\begin{array}{l}\boldsymbol{R} \\
\text { Square }\end{array}$ & $\begin{array}{l}\text { Adjusted } \\
\boldsymbol{R} \text { Square }\end{array}$ & $\begin{array}{l}\text { Std. Error of } \\
\text { the Estimate }\end{array}$ & $\begin{array}{l}\text { Durbin- } \\
\text { Watson }\end{array}$ \\
\hline $\boldsymbol{1}$ & $.991 a$ & .981 & .980 & .10967 & .619 \\
\hline
\end{tabular}

Predictors: (Constant), Ln_inflasi, Ln_BI-7day, Ln_DPK, Ln_fee based income Dependent Variable: Ln_Profitabilitas

Berdasarkan tabel di atas dapat dilihat nilai Durbin-Watson pada model summary adalah sebesar 0,619. Berdasarkan pedoman pengujian Durbin-Watson atau nilai D-W maka hasil analisis menunjukkan bahwa angka D-W sebesar $+0,619$ berada di antara -2 dan +2 sehingga terbebas dari autokorelasi.

\section{Analisis Regresi Linier Berganda}

Tabel 5. Hasil Uji Regresi Linier Berganda

\begin{tabular}{|c|c|c|c|c|c|}
\hline \multirow[t]{2}{*}{ Model } & \multicolumn{2}{|c|}{$\begin{array}{l}\text { Unstandardized } \\
\text { Coefficients }\end{array}$} & \multirow{2}{*}{$\begin{array}{l}\text { Standardized } \\
\text { Coefficients } \\
\text { Beta }\end{array}$} & \multirow[t]{2}{*}{$t$} & \multirow[t]{2}{*}{ Sig.6 } \\
\hline & $B$ & $\begin{array}{l}\text { Std. } \\
\text { Error }\end{array}$ & & & \\
\hline 1(Constant) & -9.183 & 1.369 & & -6.709 & .0006 \\
\hline Ln_Inflasi & -.073 & .068 & -.034 & -1.071 & 288 \\
\hline
\end{tabular}




\begin{tabular}{llllll}
$\begin{array}{l}\text { Ln_BI 7-day reserve } \\
\text { reporate }\end{array}$ & .020 & .094 & .005 & .211 & .834 \\
$\begin{array}{l}\text { Ln_DPK } \\
\begin{array}{l}\text { Ln_fee } \\
\text { income }\end{array}\end{array}$ & .664 & .075 & .259 & 8.853 & .000 \\
\hline
\end{tabular}

a. Dependent Variable: Ln_Profitabilitas

Berdasarkan tabel di atas maka dalam penelitian ini dapat digambarkan persamaan regresi sebagai berikut:

$$
\mathrm{Y}=-9.183-0,073(\mathrm{X} 1)+0,020(\mathrm{X} 2)+0,664(\mathrm{X} 3)+0,917(\mathrm{X} 4)
$$

Profitabilitas $=-9,183-0,073($ Inflasi $)+0,020($ BI 7-Day Reserve Repo Rate $)+$ 0,664 (DPK) + 0,917 (Fee Based Income) Interprestasi :

Nilai a $=-9,183$ artinya jika Inflasi $\left(X_{1}\right)=0, B I-7$ days reserve repo rate $\left(X_{2}\right)=0$, dana pihak ketiga $\left(\mathrm{X}_{3}\right)=0$, fee based income $\left(\mathrm{X}_{4}\right)=0$, maka profitabilitas pada $\mathrm{BNI}$ Syariah (Persero) Tbk adalah sebesar 9,183\%.

Nilai $b_{1}=-0,073$ uartinya jika tingkat Inflasi meningkat sebesar $1 \%$,- maka profitabilitas BNI Syariah (Persero) Tbk akan menurun sebesar 0,073\%. Hal ini menunjukkan bahwa koefisen untuk variabel ini bernilai negatif.

Nilai $b_{2}=0,020$ artinya jika tingkat BI 7-day reserve repo rate meningkat sebesar $1 \%$ maka profitabilitas BNI Syariah (Persero) Tbk akan meningkat sebesar 0,020\%. Hal ini menunjukkan bahwa koefisien untuk variabel ini bernilai positif. Dapat disimpulkan bahwa semakin tinggi tingkat $\mathrm{BI} 7$-day reserve repo rate maka profitabilitas pada $\mathrm{BNI}$ Syariah (Persero) Tbk akan semakin meningkat.

Nilai $b_{3}=0,664$ artinya jika dana pihak ketiga meningkat sebesar Rp 1,- maka profitabilitas BNI Syariah (Persero) Tbk akan meningkat sebesar 0,664\%. Hal ini menunjukkan bahwa koefisien untuk variabel ini bernilai positif.

Nilai $\mathrm{b}_{4}=0,917$ artinya jika fee based income meningkat sebesar Rp 1,- maka profitabilitas BNI Syariah (Persero) Tbk akan meningkat sebesar 0,917\%. Hal ini menunjukkan bahwa koefisien untuk variabel ini bernilai positif.

\section{Koefisien Determinasi}

\begin{tabular}{|c|c|c|c|c|c|}
\hline Model & $R$ & $\begin{array}{l}R \\
\text { Square }\end{array}$ & $\begin{array}{l}\text { Adjusted } R \\
\text { Square }\end{array}$ & $\begin{array}{l}\text { Std. Error of } \\
\text { the Estimate }\end{array}$ & $\begin{array}{l}\text { Durbin- } \\
\text { Watson }\end{array}$ \\
\hline 1 & $.991 a$ & .981 & .980 & .10967 & .619 \\
\hline $\begin{array}{l}\text { a. } \\
\text { ome }\end{array}$ & Predictors: (C & (onstant), I & n_inflasi, $L n \_L$ & I-7day, Ln_DPK & Ln_fee based \\
\hline
\end{tabular}

Berdasarkan tabel Model Summary di atas, dapat diketahui bahwa nilai $R$ Square atau koefisien determinasi sebesar 0,981. Artinya kemampuan variabel independen yang meliputi inflasi, BI 7-day reserve repo rate, dana pihak ketiga, dan fee based income dalam menerangkan variasi perubahan profitabilitas adalah sebesar 98,1\% sedangkan $1,9 \%$ sisanya dipengaruhi oleh faktor atau variabel lain di luar penelitian yang dilakukan. 


\section{Uji t (Parsial)}

Tabel 7. Hasil Uji t (Parsial)

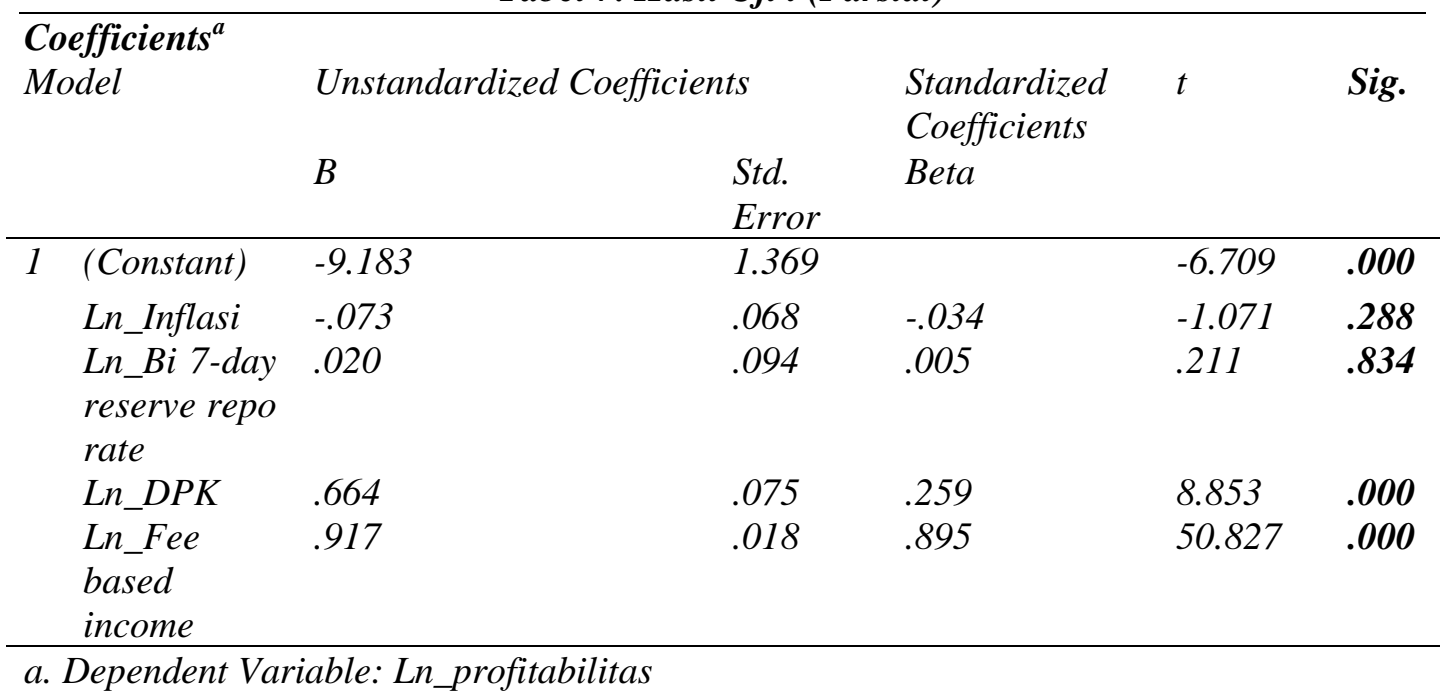

\section{Uji F (Simultan)}

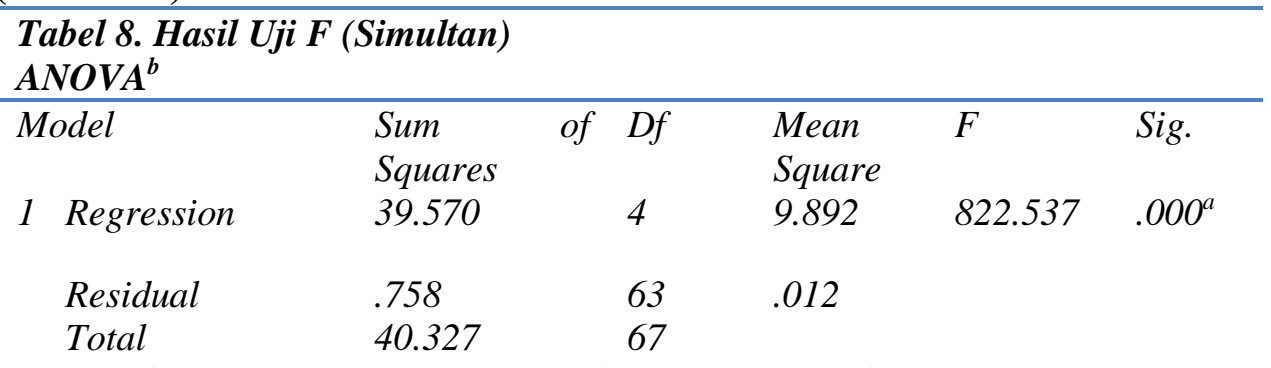

a. Predictors: (Constant), Ln_inflasi, Ln_BI 7-day,

Ln_DPK, Ln_Fee based income

b. Dependent Variable:

Ln_Profitabilitas

\section{Pengaruh Inflasi Terhadap Profitabilitas}

Dari tabel 7 Coefficients di atas menunjukkan bahwa nilai thitung inflasi sebesar 1,071 dan $\mathrm{t}_{\text {tabel }}$ sebesar 1,998. Nilai $\mathrm{t}_{\text {hitung }}<\mathrm{t}_{\text {tabel }}$ yaitu $(1,071)<(1,998)$ maka $\mathrm{H}_{0}$ diterima atau tolak $\mathrm{H}_{\mathrm{a}}$ artinya bahwa variabel inflasi tidak berpengaruh terhadap profitabilitas. Pada tabel 7 Coefficients diatas menunjukkan nilai signifikansi inflasi sebesar 0,288 dan nilai taraf signifikansi sebesar 0,05 . Nilai Sig. $>\alpha$ yaitu $0,288>0,05$ maka $\mathrm{H}_{0}$ diterima atau tolak $\mathrm{H}_{\mathrm{a}}$ artinya bahwa variabel inflasi tidak berpengaruh signifikan terhadap profitabilitas. Hasil penghitungan menunjukkan hasil uji bahwa $\mathrm{H}_{0}$ diterima dan $\mathrm{H}_{\mathrm{a}}$ ditolak, artinya secara parsial variabel inflasi berpengaruh negatif tapi tidak signifikan terhadap profitabilitas pada BNI Syariah (Persero) Tbk periode 2015 sampai dengan 2020.

Hasil ini mengindikasikan bahwa tinggi rendahnya perubahan yang terjadi pada tingkat inflasi tidak mempengaruhi produktivitas perbankan syariah dalam menghasilkan keuntungan. Hasil penilitian ini sependapat dengan penelitian yang telah dilakukan oleh I Gede Putra Adyatmika dan I Gusti Bagus Wiksuana (2018), Edhi Satria Wibowo dan Muhammad Syaichu (2013). Penelitian tersebut menyatakan bahwa inflasi berpengaruh negatif dan tidak signifikan terhadap profitabilitas. Hal ini menunjukkan bahwa meskipun 
inflasi mengalami kenaikan, namun laba atau profit yang diperoleh perusahaan tidak mengalami penurunan yang signifikan dan sebaliknya. Sehingga dapat berdampak buruk terhadap individu dan masyarakat karena menurunnya tingkat kesejahteraan masyarakat dan buruknya distribusi pendapatan hal ini seperti yang dikemukakan oleh Pratama Rahardja dan Mandala Manurung.

\section{Pengaruh BI 7-Day Reserve Repo Rate Terhadap Profitabilitas}

Dari tabel 7 Coefficients di atas menunjukkan bahwa nilai thitung BI 7 day reserve reporate sebesar 0,211 dan $\mathrm{t}_{\text {tabel }}$ sebesar 1,998. Nilai $\mathrm{t}_{\text {hitung }}<\mathrm{t}_{\text {tabel }}$ yaitu $(0,211)<(1,998)$ maka $\mathrm{H}_{0}$ diterima atau tolak $\mathrm{H}_{\mathrm{a}}$ artinya bahwa variabel $\mathrm{BI} 7$ day reserve reporate tidak berpengaruh terhadap profitabilitas.

Pada tabel 7 Coefficients menunjukkan nilai signifikansi BI 7 day reserve reporate sebesar 0,834 dan nilai taraf signifikansi sebesar 0,05 . Nilai Sig. $>\alpha$ yaitu $0,834>0,05$ maka $\mathrm{H}_{0}$ diterima atau tolak $\mathrm{H}_{\mathrm{a}}$ artinya bahwa variabel $\mathrm{BI} 7$ day reserve reporate tidak berpengaruh signifikan terhadap profitabilitas.

Hasil penghitungan menunjukkan hasil uji bahwa $\mathrm{H}_{0}$ diterima dan $\mathrm{H}_{\mathrm{a}}$ ditolak, artinya secara parsial BI 7-day reserve repo rate berpengaruh positif tapi tidak signifikan terhadap profitabilitas pada BNI Syariah (Persero) Tbk periode 2015 sampai dengan 2020. Hasil ini menjelaskan bahwa besar atau kecilnya tingkat suku bunga acuan yang ditetapkan oleh Bank Indonesia tidak mempengaruhi kemampuan perbankan syariah dalam upaya memperoleh keuntungan. Hasil penelitian ini sependapat dengan penelitian yang telah dilakukan oleh Martha Ayerza (2018), Fifi Nurafifah Ibrahim., Nurfadillah dan Hukma Ratu Purnama (2019) yang menyatakan bahwa suku bunga acuan (BI 7-day reserve repo rate) berpengaruh positif namun tidak signifikan terhadap profitabilitas.

Penelitian ini menegaskan bahwa BNI Syariah mampu menjaga stabilitas dalam memperoleh keuntungan dibawah tekanan fluktuasi suku bunga acuan atau BI 7-day reserve repo rate. Pada konsepnya teori Keynes menyatakan bahwa tingkat suku bunga memberikan kecenderungan fungsional yang menentukan jumlah uang yang diberikan, hal ini berpengaruh terhadap perilaku masyarakat yang ingin menghindari risiko dan memaksimalkan keuntungan.

\section{Pengaruh Dana Pihak Ketiga Terhadap Profitabilitas}

Dari tabel 7 Coefficients di atas menunjukkan bahwa nilai thitung DPK sebesar 8,853 dan $t_{\text {tabel }}$ sebesar 1,998 . Nilai thitung $>t_{\text {tabel }}$ yaitu $(8,853)>(1,998)$ maka $\mathrm{H}_{0}$ ditolak atau terima $\mathrm{H}_{\mathrm{a}}$ artinya bahwa variabel DPK berpengaruh terhadap profitabilitas.

Pada table 7 Coefficients menunjukkan nilai signifikansi DPK sebesar 0,000 dan nilai taraf signifikansi sebesar 0,05 . Nilai Sig. $<\alpha$ yaitu $0,000<0,05$ maka $\mathrm{H}_{0}$ ditolak atau terima $\mathrm{H}_{\mathrm{a}}$ artinya bahwa variabel DPK berpengaruh signifikan terhadap profitabilitas.

Hasil penghitungan menunjukkan hasil uji bahwa $\mathrm{H}_{0}$ ditolak dan $\mathrm{H}_{\mathrm{a}}$ diterima, artinya secara parsial variabel dana pihak ketiga berpengaruh positif dan signifikan terhadap profitabilitas pada BNI Syariah (Persero) Tbk periode 2015 sampai dengan 2020. Hasil ini mengindikasikan bahwa besar atau kecilnya dana yang didapat bank dari masyarakat mempengaruhi kemampuan perbankan syariah dalam upaya memperoleh keuntungan. Penelitian ini sependapat dengan penelitian yang telah dilakukan oleh Sudarmin Parenrengi dan Tyahya Whisnu Hendratni, Dila Angraini (2018) yang 
menyimpulkan bahwa variabel dana pihak ketiga berpengaruh signifikan terhadap profitabilitas.

Penelitian ini mengaskan bahwa dana yang didapat oleh BNI Syariah dari nasabah dalam bentuk tabungan, giro, dan deposito yang berdasarkan akad Wadi'ah dan Mudharabah memiliki dampak yang signifikan dalam upaya memperoleh keuntungan. Secara teori yang dikemukakan oleh (Kasmir, 2012) bahwa dana pihak ketiga merupakan tolak ukur keberhasilan suatu bank apabila bank dapat menanggung biaya operasionalnya yang berasal dari dana tersebut.

\section{Pengaruh Fee Based Income Terhadap Profitabilitas}

Dari tabel 7 Coefficients di atas menunjukkan bahwa nilai $t_{\text {hitung }}$ fee based income sebesar 50,827 dan $t_{\text {tabel }}$ sebesar 1,998. Nilai $t_{\text {hitung }}>t_{\text {tabel }}$ yaitu $(50,827)>(1,998)$ maka $\mathrm{H}_{0}$ ditolak atau terima $\mathrm{H}_{\mathrm{a}}$ artinya bahwa variabel fee based income berpengaruh terhadap profitabilitas.

Pada table 7 Coefficients menunjukkan nilai signifikansi fee based income sebesar 0,000 dan nilai taraf signifikansi sebesar 0,05 . Nilai Sig. $<\alpha$ yaitu $0,000<0,05$ maka $\mathrm{H}_{0}$ ditolak atau terima $\mathrm{H}_{\mathrm{a}}$ artinya bahwa variabel fee based income berpengaruh signifikan terhadap profitabilitas.

Hasil penghitungan menunjukkan hasil uji bahwa $\mathrm{H}_{0}$ ditolak dan $\mathrm{H}_{\mathrm{a}}$ diterima, artinya secara parsial variabel fee based income berpengaruh positif signifikan terhadap profitabilitas pada BNI Syariah (Persero) Tbk periode 2015 sampai dengan 2020. Hasil ini mengindikasikan bahwa besar atau kecilnya fee atau komisi yang didapat bank diluar dari kegiatan operasional mempengaruhi kemampuan perbankan syariah dalam upaya memperoleh keuntungan. Hasil penelitian sependapat dengan penelitian yang telah dilakukan oleh oleh Vivi Indah Bintari., Allicia Deana Santosa dan Risna Amalia Hamzah (2019) , Putu Ayuni Kartika Putri Suardana dan Ketut Tanti Kustina (2017) menyimpulkan bahwa variabel fee based income berpengaruh signifikan terhadap profitabilitas. Penelitian ini menegaskan bahwa pendapatan fee based income yang didapatkan oleh BNI Syariah meliputi transaksi dari akad ijarah, wakalah, kafalah, dan hawalah mampu memberikan peran yang signifikan dalam upaya memperoleh keuntungan. Menurut (Sri Langgeng Ratnasari, 2017:70) perolehan keuntungan dari jasajasa bank ini walaupun relatif kecil, namun memberikan suatu kepastian dikarenakan risiko terhadap jasa bank ini lebih kecil dibandingkan dengan kredit.

\section{Pengaruh Inflasi, BI 7-Day Reserve Repo Date, Dana Pihak Ketiga dan Fee Based Income Terhadap Profitabilitas.}

Dari tabel 8 Anova diperoleh $\mathrm{F}_{\text {hitung }}$ sebesar 822,537 dan nilai probabilitas (Sig.) sebesar 0,000. Nilai $F_{\text {hitung }}(822,537)>F_{\text {tabel }}(2,518)$ maka $\mathrm{H}_{0}$ ditolak atau terima $\mathrm{H}_{\mathrm{a}}$. Begitu pula dengan nilai Sig. $(0,000)<\alpha(0,05)$ maka $\mathrm{H}_{0}$ ditolak atau terima $\mathrm{H}_{\mathrm{a}}$. Hal ini berarti inflasi, BI 7 day reserve reporate, DPK dan fee based income secara simultan berpengaruh terhadap profitabilitas.

Berdasarkan uji F yang dilakukan peniltian menunujukan variabel inflasi, BI 7Day Reserve Repo Date, Dana Pihak Ketiga dan Fee Based Income secara bersama-sama terhadap profitabilitas. Artinya jika inflasi, BI 7-Day Reserve Repo Date, Dana Pihak Ketiga dan Fee Based Income mengalami peningkatan maka profitabilitas akan naik. Sebaliknya jika inflasi, BI 7-Day Reserve Repo Date, Dana Pihak Ketiga dan Fee Based Income mengalami penurunan maka profitabilitas juga akan turun. 


\section{KESIMPULAN}

Berdasarkan pemaparan sebelumnya maka dapat disimpulkan bahwa variabel inflasi tidak berpengaruh signifikan terhadap profitabilitas BNI Syariah (Persero) Tbk periode 2015 sampai dengan periode 2020. Variabel BI 7-day reserve repo rate tidak berpengaruh signifikan terhadap profitabilitas BNI Syariah (Persero) Tbk periode 2015 sampai dengan periode 2020. Variabel dana pihak ketiga berpengaruh positif signifikan terhadap profitabilitas BNI Syariah (Persero) Tbk periode 2015 sampai dengan periode 2020. Variabel fee based income berpengaruh positif signifikan terhadap profitabilitas BNI Syariah (Persero) Tbk periode 2015 sampai dengan periode 2020.

Adapun implikasi kebijakan yang dapat peneliti berikan untuk penelitian selanjutnya adalah: 1. Bagi perbankan, Dengan adanya penelitian ini diharapkan perusahaan bisa lebih aware terhadap risiko pada sekto makroekonomi dan penghimpunan dana 2. Bagi peneliti selanjutnya, Diharapkan penelitian selanjutnya dilakukan dengan minimal menggunakan variabel yang sama ataupun menambah variabel lain dengan sampel penelitian yang berbeda dan teraktual, objek penelitian tidak harus berasal dari sektor perbankan, diperkanakan yang berasal dari sektor lain seperti sektor perusahaan yang go publik dan tidak berfokus pada satu subsector saja agar penelitian dapat di generalisasi dan disempurnakan.

\section{REFERENSI}

Adyatmika, I. G. P., \& Wiksuana, I. G. B. (2018). Pengaruh Inflasi dan Leverage Terhadap Profitabilitas dan Return Saham Pada Perusahaan Manufaktur di Bursa Efek Indonesia. Jurnal Ekonomi dan Bisnis Universitas Udayana, Vol.7, No. 2.

Andrianto \& Firmansyah, M. A. (2019). Manajemen Bank Syariah (Implementasi Teori dan Praktek). Surabaya: Qiara Media.

Angraini, D. (2018). Pengaruh Dana Pihak Ketiga, Non Perfoming Financing, Tingkat Bagi Hasil Dan Modal Sendiri Terhadap Profitabilitas Dengan Pembiayaan Bagi Hasil Sebagai Variabel Intervening Pada Perbankan Syariah. Jurnal Akuntansi Berkelanjutan Indonesia Universitas Esa Unggul, Vol. 1, No. 1.

Ayerza, M. (2018). Analisis Pengaruh Tingkat Suku Bunga Dan Inflasi Terhadap Profitabilitas Perbankan Yang Terdaftar Di Bursa Efek Indonesia Periode 20102016. Jurnal Manajemen Keuangan Institut Bisnis Dan Informatika Kwik Kian Gie, Vol. 8, No. 1.

Bintari, V. I., Santosa, A. D., \& Hamzah, R. A. (2019). Pengaruh Interest Based Income Dan Fee Based Income Terhadap Return On Assets Pada Bank Mandiri (PERSERO) TBK. Jurnal Ekonomi Manajemen Universitas Siliwangi, Vol. 5, No. 1.

Husaeni, U. A. (2017). Analisis Pengaruh Dana Pihak Ketiga Dan Non Perfoming Financing Terhadap Return On Asset Pada BPRS Di Indonesia. EQUILIBRIUM: Jurnal Ekonomi Syariah Stain Kudus, Vol. 5, No. 1.

Ibrahim, F. N., Nurfadillah., \& Purnama, H. R. (2019). Pengaruh Tingkat Suku Bunga Dan Tingkat Inflasi Terhadap Profitabilitas Pada Perusahaan Manufaktur Di Bursa Efek Indonesia. Jurnal Ilmu Akuntansi Peradaban, Vol. 5, No. 2. 
Iqbal, Z., \& Abbas, M. (2013). Economic Development and Islamic Finance. Washington, D.C: The World Bank.

Kalengkongan, G. (2013). Tingkat Suku Bunga dan Inflasi Pengaruhnya Terhadap Return On Asset (ROA) Pada Industri Perbankan Yang Go Public Di Bursa Efek Indonesia. Jurnal EMBA Fakultas Ekonomi dan Bisnis Jurusan Manajemen Universitas Sam Ratulangi Manado, Vol. 1, No. 4.

Kasmir. (2012). Bank dan Lembaga Keuangan Lainnya. Jakarta: PT Raja Grafindo Persada.

Keynes, J. M. (2018). The General Theory Of Employment, Interest and Money Introduction By Paul Krugman After Word By Robert Skidelksy. United Kingdom: Palgrave Macmillan.

Langdana, F. K. (2016). Macroeconomic Policy Demystifying Monetary and Fiscal Policy Third Edition. Switzerland: Springer International Publishing AG Switzerland.

Lindayani, N. W., \& Dewi, S. Kt. S. (2016). Dampak Struktur Modal dan Inflasi Terhadap Profitabilitas dan Return Saham Perusahaan Keuangan Sektor Perbankan. E-Jurnal Manajemen Fakultas Ekonomi dan Bisnis Universitas Udayana, Vol. 5, No. 8.

Massie, G. M. (2014). Pengaruh Fee Based Income Dan Intellectual Capital Terhadap Profitabilitas Pada dustri Perbankan Di Bursa Efek Indonesia. e-Jurnal Katalogis, Vol. 2, No. 7.

Pandia, F. (2012). Manajemen Dana dan Kesehatan Bank. Jakarta: Rineka Cipta.

Parenrengi, S., \& Hendratni, T. W. (2018). Pengaruh Dana Pihak Ketiga, Kecukupan Modal Dan Penyaluran Kredit Terhadap Profitabilitas Bank. Jurnal Manajemen Strategi dan Aplikasi Bisnis LPMP Imperium. Vol. 1, No. 1.

Pusat Data dan Analisa Tempo. (2018). Inflasi : Mengurai Penyebab Utama Terjadinya Inflasi Yang Terjadi Sepanjang Tahun. Jakarta: TEMPO Publishing

Rahardja, P., \& Manurung, M. (2008). Pengantar Ilmu Ekonomi: Mikro Ekonomi \& Makro Ekonomi. Jakarta: LPFE-UI.

Ratnasari, S. L. (2012). Bank dan Lembaga Keuangan Lainnya. UPN Press.

Razid, M., \& Antonioni, P. (2015). Macroeconomics For Dummies. United Kingdom: John Wiley \& Sons, Ltd.

Rist, M., \& Pizzica, A. J. (2015). Financial Ratios For Executives. United State: Apress.

Sahara, A. Y. (2013). Analisis Pengaruh Inflasi, Suku Bunga BI, Dan Produk Domestik Bruto Terhadap Return On Assets (ROA) Bank Syariah Di Indonesia. Jurnal Ilmu Manajemen Fakultas Ekonomi Universitas Negeri Surabaya, Vol. 1, No.1.

Schoon, N. (2016). Modern Islamic Banking Product and Processes in Practice. United Kingdom: John Wiley \& Sons, Ltd.

Suardana. P. A. K. P., \& Kustina, K. T. (2017). Pengaruh Fee Based Income Dan Transaksi E-Banking Terhadap Perubahan Laba Pada PT. Bank Pembangunan 
Daerah Bali. Jurnal Ilmiah Akuntansi dan Bisnis Universitas Pendidikan Nasional, Vol. 2, No. 2.

Suseno., \& Astiyah, S. (2009). Inflasi. Jakarta: Pusat Pendidikan dan Studi Kebanksentralan (PPSK) Bank Indonesia.

Syah, T. A. (2018). Pengaruh Inflasi BI Rate, NPF, dan BOPO Terhadap Profitabilitas

Bank Umum Syariah di Indonesia. El- JIZYA Jurnal Ekonomi Islam IAIN Purwokerto, Vol. 6, No. 1.

Website BI. Data Inflasi Bulanan Tahun 2015- 2020. Bank Indonesia.

Website BI. Data BI 7-Day Reserve Repo Rate Tahun 2015- 2020. Bank Indonesia.

Website BNI Syariah. Laporan Keuangan Bulanan Tahun 2015- 2020.

Wibowo, E. S., \& Syaichu, M. (2013). Analisis Pengaruh Suku Bunga, Inflasi, CAR, BOPO, NPF Terhadap Profitabilitas Bank Syariah, Diponegoro Journal Of Management Jurusan Manajemen Fakultas Ekonomika dan Bisnis Universitas Diponegoro, Vol. 2, No. 2.

Zulifiah, F., \& Susilowibowo, J. (2014). Pengaruh Inflasi, BI Rate, Capital Adequacy Ratio (CAR), Non Perfoming Loan (NPF), Biaya Operasional dan Pendapatan Operasional (BOPO) Terhadap Profitabilitas Bank Umum Syariah Periode 20082012. Jurnal Ilmu Manajemen Universitas Negeri Surabaya, Vol. 2, No. 3. 